\title{
The Development of Diorama Learning Media Transportation Themes to Develop Language Skill Children's Group B
}

\author{
Usep Kustiawan $^{\mathrm{a}}$ \\ ${ }^{a}$ Malang State University, Malang, Indonesia, usepkustiawan@gmail.com, ORCID 0000-0001-9370- \\ 0505
}

\begin{abstract}
Early Childhood is the beginning of basic skills development, and one such skill is the language skill. During this time, appropriate stimulus is required to assist the optimal development of children's language skills, which includes the utilization of effective media learning in kindergarten. Field observation obtained by the researcher in Kindergarten PGRI 3 Tulusayu Tumpang Malang district showed that the only learning media currently used is in the form of visual utilities exhibited by the teacher and does not involve many children in the utilization. The purpose of this research and development is to produce an instructional media diorama that can be used as a language development tool for children in language skill group B. The learning media diorama is expected to help teachers to be more creative in using learning media as interactive game tools.
\end{abstract}

Keywords: Diorama, language skill, media learning

\section{Introduction}

Early childhood is a stage of behavioural development that includes the initial development of religious, moral, social, and emotional values, as well as basic language, cognitive, physical-motor, and artistic skills. Parents and teachers increasingly understand that early childhood is an age where children will experience rapid growth and development. Montessori (in Sujiono, 2009, p. 2) states that 'in the age range of birth to six years of children experience the golden years which is a significant or sensitive period of children's potentials to receive various stimuli". In order for children to explore and develop their full potential, an encouraging environment is required.

One aspect that develops at an early age is children's language aspect. Dhieni, et al (2012: 1.3) suggests that 'language is a symbolic system for communicating with others, including creativity and system of rules'. Language aspect is one of the children development aspects that requires to be considered, because the main function of language for children is to communicate with others. Children's language skills cannot automatically be self-controlled by the children, but through active communication with others and the use of appropriate and precise language will stimulate children's language skill development. This can occur rapidly and easily, when children receive or learn the language from the environment where they are located in a fun way.

In the Curriculum 2013 for Early Childhood Education, there are various development programs. The development program is the embodiment of learning atmosphere for behaviour's development, maturity of thinking, kinaesthetic, language, social, emotional, and language through game activities. Learning atmosphere is defined as anything that can encourage children's interest to learn.

Language development program means that there are teachers who master appropriate communication techniques to help achieve expressive and receptive language maturity. The resource ability, tools and time that children can use to practice language and the ability to identify early literacy is carried out as a fun learning process. There are various ways to develop children's language skill; one such way is the use of media learning for game activities that are interesting, fun, and safe for children.

Media learning is everything that is used by teachers to convey the subject material to the students; therefore, the students are interested in terms of their attentiveness and consideration, stimulated and their feelings on learning 
activities in order to achieve the learning objectives (Kustiawan, 2013: 3). According to Gagne (in Arsyad, 2004: 5) the media are the various types of components within a protégé environment that can encourage students to learn.

A diorama is a three-dimensional miniature scene created to demonstrate or explain an event or phenomenon that indicates an activity (Munadi, 2008, p. 109). Within the diorama, there are additional three-dimensional miniatures that would populate the real-life scenes; for example, a scarecrow, trees, houses, and so on. In other words, a diorama is a mini three-dimensional tableau that aims to represent a scene realistically (Sudjana \& Rivai, 2010, p. 170). Dioramas usually consist of figures or objects placed in front of a painted background.

Playing is a spontaneous and natural activity with or without the use of fun tools for children, while a game is a form of play that has rules for its implementation. A good game is to develop all of children's aspects in order to be a good person and fun for the children. Triharso (2013: 11) states that pre-schoolers in the age group of 4-6 years enjoy a challenging game and move their muscles, doodles, reads, and so on, and use many tools in activities such as geometry blocks, plastic, and so on.

Based on the preliminary results of observations conducted by the researcher on learning activities in group B Kindergarten PGRI 3 Tulusayu Tumpang Malang district, it is shown that: (1) learning tends to be done only by using common media; (2) the teacher shows only a small two-dimensional image, which causes the child to be too unmotivated and bored to understand its significance; (3) children require new learning media and; (4) learning seems less developed language skill.

From the above indicators, some factors can be identified that impede learning, namely (1) the media used by teachers is not varied; (2) the learning method is less interesting; and (3) it is known that children in group B prefer media learning that can be seen from all directions (three dimensions), yet the media used is only two dimensional. To solve these problems, an alternative three-dimensional learning media tool is required, which makes children interested and can develop their imagination and freedom of thought.

Teaching and learning activities to develop the language skills of the group B children in Kindergarten PGRI 3 Tulusayu Tumpang Malang district are less varied and tend to be less interesting for the children. It is necessary to develop teaching and learning activities for children that use interesting, fun, and safe learning media tools.

The results of the interviews with one of the teachers at Kindergarten PGRI 3 Tulusayu Tumpang Malang Regency indicated that: (1) the school has never used play activities for developing children's language skills that utilize diorama-based media learning, (2) teachers agree that diorama media learning should be developed in the school.

The above circumstantial evidence has encouraged the researcher to conduct a development research study entitled 'Development of Diorama Learning Media on Transportation to Develop Language Ability of Group B Children'.

\section{Method}

The research method was conducted in Group B Kindergarten PGRI 3 Tulusayu Tumpang Malang district using research and development. The research implementation and language skill development was conducted by utilizing this diorama learning media using the development procedure according to Borg and Gall consisting of ten steps, but the ten steps proposed by Borg and Gall are not the standard steps to be followed unconditionally. Therefore, the researcher modified the process into seven steps, while the eighth, ninth, and tenth steps were not implemented. The seven steps are: (1) Research and information collection (literature review, classroom observation, preparing reports on the subject matter); (2) Planning (defining skills, formulating objectives, determining teaching sequences); (3) Developing product forms the beginning of the diorama medium to be tested; (4) Conducting a small start-up trial that was conducted on the first Class B, using 6-8 subjects; (5) Main product revision (in accordance with the suggestions of the small group trial results); (6) Main field testing with 15 to 20 subjects in the second Class B; (7) Operational product revision (product revision based on suggestions from the main field test results) (Borg and Gall, 1983).

The data analyses used in this research and development project, as well as the experts' evaluations for the trial, include both qualitative and percentage-based quantitative techniques. Qualitative analysis is used to analyse the qualitative data collected from experts, which includes the following categories: early childhood learning, early media learning, and early childhood linguists in the suggestions form and inputs used to revise the product design. Analysis of percentages is used to quantify the results of data collection in the initial study (needs analysis from experts), the small group trial results, and the field trial results (with large groups). 


\section{Results and Discussions}

\subsection{Results}

The product developed in the course of this project is a diorama-based learning tool that can develop the language skills of children in group B. This diorama is only used for learning on the theme of transportation and the subtheme of types of transportation (land, water and air-based). This diorama-shaped learning tool takes the form of a box, on the back of which is a two-dimensional view of an air transportation image; at the bottom, a three-dimensional relief containing models of land, marine and air transportation; on the left and right sides, semi-transparent glass with corners coated in thick duct tape (so as to prevent harm to the children); and on the outside rear, the flannel board for pasting letter cards, word cards, and picture cards.

The utilization of an instructional diorama for language learning in group B Kindergarten PGRI 3 Tulusayu Tumpang Malang district may take the form of the following activity. The preparatory stage: 1) Teacher and children pray, then greet each other; 2) Teacher checks the attendance list; 3) Teacher performs a question-and-answer task with the children about the day's themes and subthemes; 4) Teacher prepares the dioramas for use in language learning. The main activity: 1) The teacher introduces the instructional diorama; 2) Children are given the opportunity to observe and ask about the contents of the diorama, 3) Teacher firstly gives examples to the children of the steps involving in using the diorama for language learning, 4) Children play games utilizing the diorama. The final stage: 1) Reflection on activities that have been implemented during the day, 2) Moral message, 3) Teacher and children sing songs about transportation, based on the sub-theme while applauding, 4) Prays, goodbyes, and going home.
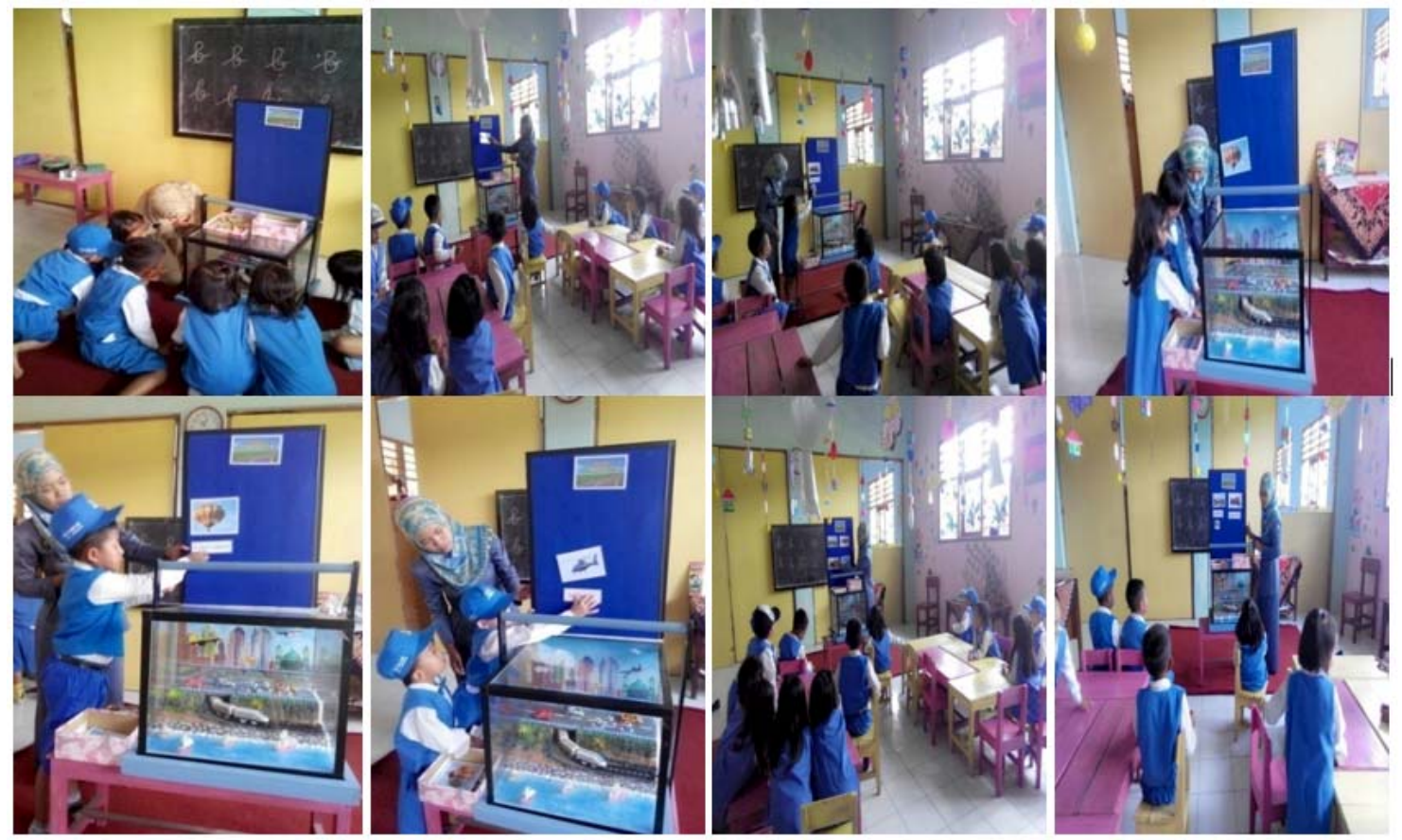

Fig 1. Kids’ Activities in Utilizing Diorama Media Learning.

The experimental review results were used as a basis for revision of the diorama learning-product design. The review was conducted by three experts, namely, an early childhood learning expert, an early childhood media learning expert, and an early childhood linguist. Expert reviews aim to determine the suitability of newly-developed products for the needs that exist in the field. From the total evaluation data, the results obtained by the early childhood learning experts gave a total value of 40 and an average percentage of $85.41 \%$. Based on the criteria used, therefore, diorama learning can be said to be valid or suitable for use. The diorama that has been designed is good and can be used as an early model in research. The evaluation data from media learning experts gave a total value of 44 with an average percentage of $91.66 \%$. Based on the criteria used, the diorama learning can be said to be valid or suitable for use. The diorama design is good and can be used as an early model in research. The evaluation data from linguists gave a total 
score of 43 with an average percentage of $89.58 \%$. Based on the criteria used, it can be said that the learning diorama is valid or practicable to use. Diorama media that has been designed is good and can be used as an early model in the research. For the total data of the experts' evaluation results the average percentage is $88.88 \%$, based on the eligibility criteria, meaning that the diorama can be said to be very valid or suitable for use.

The results of small group experiment on the preliminary product were obtained based on the observations of attractiveness, ease of use, and safety aspects of use of the instructional diorama by the classroom teacher with the group of 6 children in group B Kindergarten PGRI 3 Tulusayu Tumpang Malang district, with (2) 90.42\% of children interested in learning with the diorama, and (3) $92.85 \%$ of children are safe in doing learning activities with the diorama. For field trial (large group) conducted by using a sample of 20 children in group B, the percentages were as follows: (1) $94.28 \%$ of children find it easy to do language learning using the diorama, (2) $94.28 \%$ of children are interested in learning the language using the diorama, (3) $92.85 \%$ of children are safe learning the language using dioramas. Based on the data from the above test results, it can be said that diorama learning tools are worthy to be used to develop children's language skills.

\section{Discussion}

Teaching and learning are considered as complex processes, influenced by multiple different factors, including use of media or instructional aids that result in the active involvement of learners and make teaching more interactive. In order to make the learning experiences of the pupils more concrete and realistic, teachers have to use and prepare specific teaching materials. These instructional gadgets help teachers to clarify, establish, and correlate the learners' concepts (Naz, 2008).

The diorama learning tool represents the development of two-dimensional media, such as the blackboards and drawings from transportation-themed books which teachers currently use, into three dimensions. The diorama is an interactive learning medium that can be tailored to the contents and context of a learning activity, and which displays text, images, and models in accordance with the transportation theme. This is in line with Eliyawati's opinion (2005) that learning can be delivered more clearly, appealingly, and concretely, and should not only occur through the medium of written or verbal words.

Diorama-based learning, if used in early childhood games, fulfils one of the principles of play activities presented by Triharso $(2013$, p. 11) - that is, pre-schoolers in the four-to-six year age range enjoy challenging games and moving their muscles a lot, doodling, reading, and so on - as well as incorporating many other tools into their activities such as blocks of geometry, plastic, and so on. The diorama is used in combination with the panel plates on display at its rear, and equipped with letter cards, word cards, and vehicle image cards that are stored in the cardboard box. The letter cards, word cards, and picture cards are for children to take turns removing from the available boxes and are then affixed to the panel board according to the children's choice. They may play a game with the cards by arranging the letters into words connected to the images taped to the top. The diorama can be utilized in a series of learning activities that further develop the children's language skills.

\section{Conclusion}

The development of diorama learning tool has been a long process. From preliminary research, through product designs, to finished products that required some revisions from the experts (an early childhood learning expert, an instructional linguist, and an early childhood linguist) in order to maximize its potential, and then, lastly, trials in small groups, and field trials (large groups).

On the basis of the results of the preliminary research, designs were drafted for a diorama learning tool that could develop children's language skills. The experts who evaluated the designs offered the following suggestions: 1) Try using simple words for initial tests; 2) Consider the rules of media usage in groups for various development aspects; 3) Equip the diorama with handles for easy removal; 4) Make the product more visually interesting through use of contrasting colours for the writing and drawings; 5) Make the font size larger and use lowercase for the initial letters on the word cards; 6) Writing activities can be made into one with the game plot stick to the letter card.

After revision of the product design, the preliminary product was formed, which was tested in the research. In the small group experiment, $85.86 \%$ of children found the diorama easy to use for learning, $90.42 \%$ children were 
interested in using it, and $92.85 \%$ children felt safe using it. From the results of the small group trials, some revisions were necessary. The children had difficulty in reading certain words, prompting the researcher to amend the activity as follows: (1) after the children finished composing the letters into words, the words are read by all children; then, (2) the children are invited to repeat the word. In addition, the children experienced difficulties in the activity that involved imitating letters; the researcher made a revision by providing an initial demonstration of how to form the correct letter. The suggestion of the class teacher, as the observer, was regarding the handling of the child or the communication to be clarified to emphasise the words spoken to the children to make the atmosphere more fun.

In the field trials (large groups), $94.28 \%$ of children found the diorama easy to use for learning, $94.28 \%$ of children were happy to use it, and $92.85 \%$ of children felt safe using it.

After going through the steps detailed above, the fully-developed diorama learning tool is worthy to be used for developing children's language skills.

Suggested ideas include utilization suggestions, dissemination suggestions, and further development suggestions, as follows: 1) Utilization Suggestion: this diorama learning-development product can be used to develop group B children's language skills (age group 5-6 years). When utilizing the product, consideration needs to be given to the situation, age, and level of development of the child learners. This product is intended for group B children in Kindergarten PGRI 3 Tulusayu Tumpang Malang district, but this product can be used in other schools in accordance with the material presented and can be applied in lower classes with the difficulty level adjusted appropriately. 2) Dissemination Suggestions: (a) Before disseminating this product, it should be re-evaluated and adapted to the target situation and condition; (b) Before disseminating more widely, the product should be presented to the decision makers at the Early Childhood Education Institutions and to other schools in the vicinity, so as to obtain recognition and permission for the use of diorama-based learning. 3) Advice on Further Development: (a) For Early Childhood Education Institutes, the diorama can be rolled out as a learning tool in accordance with the characteristics and level of development of the children; (b) For teachers or educators, it should be used for play-based learning activities that are easy, fun, and safe for children, and in accordance with the characteristics of children aged 5-6 years; (c) For future researchers who wish to expand the development of instructional dioramas, it is advisable to broaden the range of its functions and applications, for example, applying it to other aspects of development beyond language acquisition.

The results of the diorama's production development process presented here only include the assessment of the product in terms of ease-of-use, attractiveness, and safety for children while performing play activities. The pedagogic effectiveness of the products has yet to be assessed; future research should therefore be conducted to assess their impact on the development of children's language skills.

\section{References}

Akhtar Naz, Ahsan., Rafaqat Ali Akbar. 2008. Use of Media for Effective Instruction its Importance: Some Consideration. Journal of Elementary Education. Vol. 18(1-2) 35-40.

Akbar, Sa'dun. (2013). Instrumen Perangkat Pembelajaran.Bandung: PT Remaja Rosdakarya.

Ardhana, W. (2001). Konsep Penelitian Pengembangan Dalam Bidang Pendidikan dan Pembelajaran. Malang: Universitas Negeri Malang.

Arsyad, Azhar. (2004). Media Pembelajaran. Jakarta: Raja Grafindo Persada.

Borg, W. R. and Gall, M. D. (1983). Educational Research An Introduction. New York: Longman.

Depdiknas, (2003). Pembuatan dan Penggunaan APE Anak Usia 3 - 6 Tahun. Jakarta: Direktorat PAUD Dirjuen PLSP.

Dhieni, Nurbiana, dkk. (2012). Metode Pengembangan Bahasa. Tangerang Selatan: Universitas Terbuka.

Eliyawati, C. (2005). Pemilihan dan Pengembangan Sumber Belajar Untuk Anak Usia Dini. Jakarta: Direktorat PPTK Dirjen Dikti.

Heinich, R. (1993). Instructional Media and the New Technologies of Instruction. New York: Mc.Millan Publishing Company.

John D. Latuheru. (2002). Media Pembelajaran Dalam Proses Belajar - Mengajar Masa Kini, Makassar State University Pers.

Kustiawan, U. (2013). Sumber dan Media Pembelajaran Anak Usia Dini. Malang: FIP UM.

Kustiawan, U. (2016). Mading Show for Early Age Child. Asian Journal of Social Sciences \& Humanities, Volume 5 Nomor 1 Februari 2016, Halaman 113-118 ISSN: 2186-8484. Japan: Leena and Luna International.

Meutia, A.C. dkk. (2003). APE untuk Kelompok Bermain. Jakarta: Direktorat PAUD Depdiknas.

Morrison, G.S. (1988). Education and Development of Infants, Toddlers, and Preschoolers. London: Scott, Foresman and Company.

Munadi, Yudhi. (2008). Media Pembelajaran. Jakarta: Gaung Persada (GP) Press. 
The Development of Diorama Media Learning Transportation Themes to Develop Language Skill Children's Group $B$

Kustiawan

Sudjana, Nana dan Rivai, Ahmad. (2010). Media Pengajaran. Bandung: Penerbit Sinar Baru Algensindo. Sudono, A. (1995). Alat Permainan dan Sumber Belajar TK. Jakarta: PPTA Dirjen Dikti.

Sugiyono. (2011). Metode Penelitian Kuantitatif, Kualitatif, dan R\&D. Bandung, Alfabeta.

Sujiono, Yuliani Nurani. (2009). Konsep Dasar Pendidikan Anak Usia Dini. Jakarta: Indeks.

Triharso, A. (2013). Permainan Kreatif dan Edukatif untuk Anak Usia Dini. Yogyakarta: Andi Offset. 